\title{
THE EMERGENCE OF GAUDIYA VAISHNAVISM IN MANIPUR AND ITS IMPACT ON NAT SANKIRTANA
}

\author{
Subhendu Manna ${ }^{*}$ 四 \\ ${ }^{* 1}$ Guest Assistant Professor, Rajiv Gandhi University
}

DOI: https://doi.org/10.29121/granthaalayah.v8.i7.2020.620

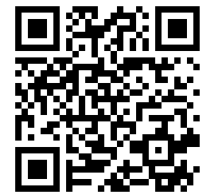

Article Type: Research Article

Article Citation: Subhendu Manna. (2020). THE EMERGENCE OF GAUDIYA VAISHNAVISM IN MANIPUR AND ITS IMPACT ON NAT SANKIRTANA. International Journal of Research -GRANTHAALAYAH, 8(7), 130-136.

https://doi.org/10.29121/granthaa layah.v8.i7.2020.620

Received Date: 02 July 2020

Accepted Date: 27 July 2020

Keywords:

Nat Sankirtana

Pung

Gaudiya Vaishnavism

\section{ABSTRACT}

The Gaudiya Vaishnavism that emerged with Shri Chaitanya in the fifteenth century continued even after his passing in the hands of his disciples and spread to far-away Manipur. Bhagyachandra - the King of Manipur along with his daughter Bimbabati Devi, visited Nabadwip and established a temple to Lord Govinda which stands till today in the village called Manipuri in Nabadwip. Therefore, the strand of Bengal's Gaudiya Vaishnavism that Bhagyachandra brought to Manipur continues to flow through the cultural life of the Manipuri people even today, a prime example of which is Nat Sankirtana. The influence of Gaudiya Vaishnavism on Nat Sankirtana is unparalleled.

\section{INTRODUCTION}

The state of Manipur, in the North-Eastern region of India, currently occupies an area of 22,327 square kilometers. It lies at a latitude of $23.50^{\circ} \mathrm{N}$ and $24.40^{\circ} \mathrm{N}$ and a longitude of $91.30^{\circ} \mathrm{E}$ and $94.30^{\circ} \mathrm{E}$. At its north lies Nagaland, at its south Mizoram. Assam is to its west and Myanmar is to the east. With the exception of Imphal, the capital, mountains, and hills cover the rest of the state. This land is home to the Meitei. They are divided into seven tribes called Yek or Salais. They are - Manging, Luwang, Khuman, Angom, Moirang, Khaba-Nganbe, and SarangLeishangthem. The neighbouring states and the country calls this land by different names.

On the other hand, the geographical location of Bengal has also changed over the course of history. Currently, Assam and Bangladesh lie to its east, the Bay of Bengal to the south, Bhutan and Sikkim to the north, and the states of Orissa and Bihar to the west. It is worth mentioning here that the district of Sylhet, now in Bangladesh, functioned as a centre of the union of Bengali and Manipuri culture from the fifteenth century onwards.

That there was a route to Bengal via Brahmadesh (Myanmar) and Manipur is mentioned in the Kamrup travels of the Chinese traveler Hiuen Tsang in the seventh century (circa 635 A.D). 
The Emergence of Gaudiya Vaishnavism in Manipur and Its Impact on Nat Sankirtana

\section{BACKGROUND}

At the end of the fifteenth century and the beginning of the sixteenth, during the reign of King Kiyamba (14671508), Vaishnavism spread to the remote state of Manipur. In or around 1470 A.D, the king of Pong (currently Myanmar) Chaufa Khigomba presented Kiyamba with a small golden statue of Vishnu as a token of affection. King Kiyamba assigned the task of worship of this statue to a Brahmin named Bhabaninath. A contemporary of Shri Chaitanyadeb, Bhabaninath was the son of Raghunath Bhagabatacharya, a resident of Barahanagar in Gaur. A temple was constructed near the palace and arrangements were made for regular worship of the deity. It is important to note that during the reign of Kiyamba, Brahmins regularly came to Manipur. During the reign of the king Khagemba (1597-1652), in the year 1635, an annual boat race with a decorated statue of Vishnu was inaugurated.

For a century, from the reign of Khagemba to the reign of Charairongba (1698-1709), Vaishnavism did not spread much in Manipur.

According to the Manipuri researcher K. B. Singh, at the first stage, Vaishnav culture entered Manipur during the reign of Charairongba (1698-1709). This level of Vaishnav tradition was called 'Nimandi' and the second level was called 'Ramandi'. This second level began during the time of Gharib Nawaz, and finally, Chaitanya or Gaudiya Vaishnav culture came to Manipur during the reign of the king Jay Singha or Bhagyachandra.

At the beginning of the eighth century, prior to the Manipuris adopting Vaishnavism, the presence of travelers, traders, and Hindu religious preachers paved the way for the spread of religion thus making it easier to preach Vaishnavism. Manipuri Amaibas and Amaibis explored ritual songs and prayers of worship and the moral processes of Lai Haraoba. In the ritual practices and prayers of 'Sanamahi', the moral character of ancient Manipuri culture becomes clear. In 'Pakhangba', the unique image of discipline and peaceful life is expressed. Again, in Phouoibee worship, the gentle nature of the land's transformation into a lush, green, fertile entity finds expression. It is to be noted that such rituals and practices carry no influence of Vaishnavism, rather, they reflect the complete picture of the structure of ancient Manipuri culture.

Nimandi began in Manipur at the end of the seventeenth century and the beginning of the eighteenth, during the reign of King Charairongba. In 1703, the king converted to Vaishnavism in the hands of Banamali, who is also known as Krishnacharya, and had come from a place called Shwetganga in Puri. Krishnacharya became a permanent resident of Manipur, and his descendants, who currently live in a place called Brahmapur, are known as Guru Aribam. Radha-Krishna idols were placed inside newly built temples and the worship began. During this time, a new cultural element known as 'Bangadesh Pala' emerged in Manipur.

Under the influence of Gaudiya Vaishnavism, many Manipuris converted to Vaishnavism. The five disciples of Narottam Thakur - Ganganarayan Chakrabarti, Nidhiram Acharya, Krishnacharan Chakrabarti, Kunjabihari Chakrabarti, and Ram Kamal Chakrabarti visited Manipur and through their sincere efforts, Vaishnavism spread through Manipur.

King Bhagyachandra converted under Paramananda Thakur, who was the disciple of Narottam Thakur's disciples. Thus, most Vaishnavites of Manipur belong to Narottam Thakur's family.

\section{PERSPECTIVE}

After adopting Gaudiya Vaishnavism, its effects and impact were clearly visible in the behavior, social practices, and lifestyle of the Manipuris. Nata Sankirtana and Rasleela became important parts of the Gaudiya Vaishnavite Manipuri society.

Shri Chaitanya, Nityananda, Adwaita, Shribas, and Gadadhar are like the sources of sankirtana. The panchatatva came from Shri Gauranga. Shribas composed music. Nityananda was the chorus, Adwaita played the mridanga with Govinda as a companion, and Gadadhar accompanied in the vocals. Mukunda, Murari, and other devotees sang the sankirtana. Influenced by this tradition, the Manipuri Vaishnavites also started sankirtana. In this sankirtana, flower, sandalwood, incense, lamp, and pana tangla (betel leaf) is used along with five vessels to invoke the panchatatva. Fulfilment of the three wishes and rescuing all living beings is the aim of the sankirtana.

By including the songs of Radha-Krishna leela as part of religion, they have incorporated kirtan in every aspect of social life. The Manipuris sing kirtans on the sixth day of child birth, name day, thread day, at weddings and funerals and other rituals associated with death. 
The great poet Rabindranath Tagore has thus commented, "If the soul is pure and if humans can pray sincerely to God, then there is no wish or desire in the world that God cannot fulfil." The poet's words shall be remembered for epochs to come.

\section{CELEBRATIONS}

In 1779, in the Bengali month of karttik, on the eleventh day of the moon, Bhagyachandra inaugurated the idol of Govinda. A Rasleela was held for five days at a ras mandap near the Langbathan palace. Organised by Bhagyachandra, this was the historic beginning of the rasleela in Manipur. This rasleela has now gained international renown as a form of dance-drama. In Manipuri culture, it is known as Jagoi Ras. It must be noted here that in the bhaab of the Manipuri Vaishnavites, this is known as 'Raskatopa' - that which is narrated to God as ras.

This rasleela is of five types: Maharas, Kunjaras, Basantaras, Nityaras, and Dibaras.

1) Maharas - This is performed on a full moon night in autumn following Shrimadbhagvat. In Manipur, it is celebrated on the day known as 'Mera Wafukpa'.

2) Kunjaras - The rasleela performed at the temple of Govinda on a full moon night in autumn, on the day known as 'Mera Rakhinba' is called Kunjaras.

3) Basantaras - The rasleela performed on a full moon night in spring is known as Basantaras.

4) Nityaras - The rasleela performed at any time of the year except during full moon nights in autumn and spring is known as Nityaras.

5) Dibaras - This ras is called Dibaras because it is performed during the day. Like Nityaras, it is dedicated to Shri Krishna in all seasons.

\section{NATASANKIRTANA}

In the present day, the Vaishnav sankirtana In Manipur is conducted by both men and women. The male tradition is called Nupapala and the female tradition is called Nupipala. In Nupilapa, the artists use the kartal and sing and dance according to pace and rhythm. Depending on the place and time of the performance, the Nupipala is of two types. Nupilala performed in the palace is called Raseswari Pala. Nupipala performed in rural areas on the occasion of various festivals such as jhulan, debi puja, and rath yatra is called Jalkeli Pala. Kings Jaysingha and Narasingha introduced Raseswari and Jalkeli in the Vaishnav society of Manipur. The first Raseswari performance took place in 1750 A.D during the reign of Jay Sinhga.

There is another kind of kirtan in Manipuri Vaishnavite society called 'Manoharsai'. Various songs of the different padas such as Manshikhsa, Prarthana, Bhajan, Lalasa are performed. This tradition was inaugurated by King Chandrakirti.

Sankirtana is intrinsic to Gaudiya Vaishnavism. When it came in contact with Manipur's own culture, it flourished and added to the excellence of Vaishnavite art. Bhagyachandra's contribution towards this excelling of Vaishnavite art is unprecedented. Later, the international fame of Manipuri dance as a part of Vaishnavite art and culture is also the result of the contributions of Bhagyachandra.

\section{THE BASIC STRUCTURE OF NATASANKIRTANA AND THE INFLUENCE OF GAUDIYA VAISHNAVISM}

Manipuri Vaishnavism believes that the place where Nat Sankirtan is performed the place becomes Sri Vrindavan. To them, the natasankirtana is a grand affair and as such, some rules are necessary for forming the natasankirtan mandali. According to the Manipuri Vaishnavite practice, the mandap must have eight poles. Each pillar is thought to be the equivalent of a gopini of Vrindavan. The mandap is usually divided into five parts. These are - 1. Khonghampham, 2. Kuber Mandap, 3. Randhan Mandap, 4. Drabya Mandap, and 5. Nikunja Mandap. At the entrance to the mandap is the Khonghampham where two bananas are placed on a plate and this is where the feet of the devotees are washed. On either side of this is the Kuber Mandap and the Drabya Mandap. The latter signifies the location of the goddess Bhagabati, and the Randhan mandap and Nikunja Mandap are signifiers of Laxmi and Shri Chaitanya respectively.

The Manipuri natasankirtana usually has seven male performers. Each performer is considered as one palas. Each palas has a cryptic name. The main singer of the pala is called Ishei-Hanba. The companion of Ishei-Hanba is 
called Dohar and is imagined as the symbol of the spirit of Gauranga. Two pung artists are Adwaita and Govinda who are the symbols of intellect. The palas are symbols of Murari, who is none other than Nityananda, the priest of the sankirtana.

Other than these main performers, there are also some other figures - Mandap Mapu (the Head of the mandali), Moibung Mongba, Arangpham, Sambasa (receptionist), and Sevaris (helper). In the natasankirtana mandali, Nitai is in the south, Madhabendra Puri is in the west, Srinibas is in the north, and Mukunda is in the east.

Actually, this ritual is performed to remember the five disciples - Chaitanya, Nityananda, Advaita, Gadadhar, and Srinibas. This is called 'mandir puja' (temple worship). Once this ritual comes to an end, the musical instruments to be used in the natasankirtana are covered in white cloth and placed at the centre of the mandali. This is because, in Manipuri culture, musical instruments are considered to be divine.

At the end of the mandir puja, the performers sit at the centre of the mandap in a circle facing each other, with their hands on the floor and kneeling in such a way that they are balanced on their toes. Then the main Sevari welcomes the performers by garlanding them and adorning them with sandalwood paste, and another Sevari comes and places mirrors in front of them and requests them to see their reflections. This entire ritual is known as 'Bariba' in Manipuri, but it is derived from the Bengali word 'baran' which means 'to welcome'.

Once the preparatory tasks of the pala are over, the Moingbu Khongbu and the Mandap Mapu along with some devotees come to the centre of the mandap and stand in a circle and call out victoriously in Brajabuli, "Boliho premse knaaho, Sri Radha Krishna Bhakta Prabhu Nitai Chaitanya Advaita kahat sant sadhu madhur rasa baani. Hare Hare." Then, taking the name of Chaitanya, the pung performers play "ten - ten - tat - tat - tang" thrice and along with this Moingbu Khongbu blows two conch shells and says in a loud voice, "Shri Krishna preeti anande hari bol" and the other palas also say "hare hare".

In the 'Shradhha' ceremony, the natasankirtana begins with 'Raag Achouba' which is one of the main raagas of the pung musical instrument. At the next step, this is played on the pung -

"Ginna - Gre - Dha - Dhen" It's symbolic of 'Radha Krishna'. The other pung players played with it - "Ginna Gre - Dha - Ten - Ten - tat - Tang"

The next beat is played to call upon Chaitanya in the mandap -

"Ginna - Gre - Ghin - Ta - Ghen - Ten - Ten - Ten"

In the later stage, the pung players try to recreate a complete image of Chaitanya through continuous beats. The beats keep getting faster and the Moibung Khombu blows on the conch shells.

The Isei-Hanba decides which raag is to be used. The palas keep the beat by playing the kartal.

There is a deeper meaning to the raag sung by the Isei-Hanba. It is believed that the raag is used to establish an image of Chaitanya in the mandap. Then pung players play

'Ta Ri Ta Na

Ri Ta Na Ta Na'

1) Ta: Refers to the chest

2) Ri: Refers to the navel

3) Ta: Refers to the waist

4) Na: Refers to the leg

5) Ri: Refers to the arm

6) Ta: Refers to the head

7) Na: Refers to the eyes

8) Ta: Refers to the noses

9) Na: Refers to Chaitanya's face

The beats that the pung players continuously play with the kartal is known as sancharas. Of the many kinds of sancharas, usually, the karttik sancharas is selected. The inner meaning of sancharas is the installation of the soul of Gauranga.

Once the mridanga stops playing and the song is over, the Isei-Hanba starts the 'guru bandana'. This is a guru bandana:

"Agyan timirandhasya gnyananjan shalakaya

Chokkhuru militong jeno tasmoi shrigurube namaha

International Journal of Research -GRANTHAALAYAH 
Em shikkhaguru param brahma, premdata dayalu, Agatir gati nathang, kripa abatar prabhu,

Ha gurudev tabo kripa bine kemone gaiba

Shri Gauranger leela ar Shri Radha Krishner leela."

Once the pung players are done with their bit, they return to their seats. Then the Isei-Hanba begins the 'shubha bandana' and the 'guru bandana'. Then the Isei-Hanba, through the 'Goura Chandrika', prays to Gauranga. This is an integral part of the Manipuri natasankirtana. According to the Gaudiya Vaishnavite school, one has to purify the mind and spirit, and only then can they sing natasankirtana. Here is an example of a Goura Chandrika song:

\section{Tintal (Goura Chandrika):} Song of Goura Chandrika -

Krishnado Goura oirare

Radhikagi laman adu shinglare

Basigi mahutta cheishu paimre

Khutta chura dhora loina thanamle

Sana phige thollambado

Kaupinna shilare

Krishna Krishna haina sholli toina toina

Krishna premda nagauri tattana

The Goura Chandrika is usually sung in tin taal. But the tradition of Goura Chandrika in Bengal is slightly different.

In the Manipuri natasankirtana, an important stage after the Gour Chandrika is the Rjmel. Actually, this is the final part of the bhaab. Traditionally, Manipuri natasankirtana has eight kinds of Rajmel. The Rajmel is composed of six parts - Berighat, Lambighat, Melahao, Setughat, Mel-Aonba, and Mel-Athoba. In the Berighat, the performers move clockwise in a circle on the stage and bow their heads to each other. The Isei-Hanba, Dohar, and the pung players touch each other's instruments which in Manipuri is known as 'jantra milan'. This moment is called 'Sambhog'. According to the pundits, the clockwise movement is actually a pilgrimage to Nabadwip. Then they move anti-clockwise. This is known as a pilgrimage to Vrindavan. During this time the main singer and the palas do not stop singing. This process of theirs is known as Lambhighat. After this comes another step which is called Setughat. In this stage, the Dohar plays the 'Chholam'. After the Setughat ends, another step begins. This is called 'Mel Aonaba' or 'Changing the Meaning'. Here the tune of the song may or may not change. But the rhythm and the beat will definitely change. At this stage of the natasankirtana, the singers or artists sing or play at a fast beat. There is another step called Athoba.

After Rajmel comes another step called Tanchep. At this stage of the natasankirtana, the palas, with kartals in their hands, exhibit various dance steps accompanied by song. During this step, several emotional songs based on 'abhisar' and 'anuraag' are sung.

After Tanchep comes to the step called Menkup. At this stage, the Dohar shows some of the complicated regal actions of the Cholam (dancing with the pung). The meaning of Menkup is progressively increasing union (purna sambhoga). At this stage of the natasankirtana, the songs allude to the gopis who have returned after plucking flowers and have met up with Radha and Krishna. This is expressed through the perfumed Lai sandalwood and an offering of light. The singers sing songs from the padabali. On the other hand, the departing spirit acquires the permission to be one with the gopis. This is alluded to through their collective prayers to their Lord Krishna. It is explained through Khonhampham. After this, the Isei-Hanba stoops and gives the 'pana tangla' to the Mandap Mapu. The inner meaning of all this is the eternal liberation of the departing spirit from the shackles of death.

After Menkup, the natasankirtana continues through various stages. The stages depend on the aim of that particular day. Usually, Menkup is followed by 'Baithha' which means to sit and sing. Finally, in the end, the Arangpham organises 'Phiroi' for all the performers which is a kind of felicitation. In Manipuri, this is known as 'Phiroi Thaba'. Then the palas follow the names of the six Goswamis. This is known as 'Soi Gosai'. The Nityananda prayer begins right after this and is called 'Nitai Pada' and at the same time the pung musicians also celebrate the name of Nityananda through the beats of their instruments. During the celebratory cries, the host and the other members offer their respects by lying prostrate on the ground. Finally, the Mandap Mapu announces the end of the 
The Emergence of Gaudiya Vaishnavism in Manipur and Its Impact on Nat Sankirtana

natasankirtana through celebratory cries and at the same time the palas cry 'Hare Hare' and the natasankirtana come to an end.

\section{COSTUME}

One of the main features of the Manipuri natasankirtana is the costume. Compared to costumes of natasankirtana in other parts of India, the ones in Manipur are quite striking. The natasankirtan costumes are called 'Ashtabesh' or 'Eight Dresses'. These are - Tri-Kachko Phaizom, Khoyangzet (waist wrapper), Lengiyang-Phi, Kowet, Tilak Dharan, Lugung with Leipareng, Naad-Niramalya, and Khujital. Usually, the torsos of the performers of natasankirtana remain bare. The Lenggiyang-Phi is for the shoulder and the Phizom and Khangzet is a kind of dhoti.

The costumes of natasankirtana are designed keeping in mind the philosophy of Vaishnavism. The Phizom especially is called 'Tin Banchha' or 'Three Wishes' - sweetness, love, and happiness. Khoyangzet is another important costume in the Manipuri natasankirtana tradition which has been borrowed from another Manipuri dance of Laiharaoba called 'Maibi'. This is made by stitching together two pieces of white cloth and is dedicated to Lairengthou and Lairembi which signnify Nature and Man respectively.

Another important costume of the natasankirtana is the Kowet. This is actually like a white turban. Usually, two kinds of Kowets are used. One is the Kowet Achauba and the other is the Salai Kowet. The Isen-Haibas, Dohar, and other pala performers use the Achauba, and the pung musicians use the Lasai Kowet. Usually, it is compulsory for the costumes of the performers and the devotees of natasankirtana to be white.

\section{MUSICAL INTRUMENTS USED IN NATASANKIRTANA}

The Manipuri natasankirtana is not possible without the pung. Pung is the name by which the mridanga is known in Manipur. It is different in shape and sound from the khola of Bengal and Assam. It is usually made from the wood of the jackfruit tree. The left side of the pung is called 'Maru' and the right side is called 'Manao'. Together it is called Marumanao. It is compared to Radha-Krishna. That is why it is offered prayers before the musicians play it. It is always wrapped in white cloth and a thick red belt is tied around it.

An instrument that accompanies pung is the kartal. Depending on the kirtan, usually two kinds of kartals are used. One is the 'Bangadesh Pala Kartal' and the other is the 'Natpala Kartal'. These are made of brass and are about 51.2 inches. The kartal used by female kirtaniyas is called 'Mandira'. This is used when the palas are sung during a Rasleela. The biggest kartal used during the namsankirtana is called 'Jhaal'.

In Manipuri, a conch shell is known as 'Moibung'. Those who play the conch shell are called Moibung Khongba. Moibung is an integral part of the natasankirtana which cannot begin or end without it.

\section{CONCLUSION}

The exchange of ideas between the Bengali and the Manipuri which happened in the context of religious consciousness reflected itself in the field of culture. Mutual exchange resulted in a mixed culture. The elements of Gaudiya Vaishnavism attached themselves to the traditional heritage of Manipur. 'Lai Horaoba', closely associated with the public consciousness in Manipur and a national event shows the influences of Rasleela, Natasankirtana, Gour Leela, Rakhal Ras, Udukhal and other Vaishnav elements. This mixture has lent Gaudiya Vaishnav society an unique image.

After the spread of Gaudiya Vaishnavism, Bengali language and literature gained popularity in Manipur. Maniouri pundits learned Bengali and Sanskrit. Various aspects and processes of Vaishnavism were translated into Manipuri. Other than that, Bhakti Rasamrita Sindhu and Ujjwal Nilmoni became very important to the pundits of the Manipuri Vaishnavite community and both texts were translated into Manipuri.

In conclusion, it can be said that natasankirtana is a tradition that has been passed from one generation of master-disciple to another for many years. And this master-disciple tradition has been endowed with an institutional form. It has been placed fourth in the list of heritage art and culture in India by UNESCO. Thus, one may hope that this is an art-filled with various rituals and practices which will remain a part of Manipuri's life from birth to death. Despite the aggression of consumerist culture, this shall prevail as a part of Indian cultural heritage. 


\section{PROFILE}

Subhendu Manna (b.1986). At present serving as Guest Assistant Professor at the Department of Fine Arts \& Music, Rajiv Gandhi University, Arunachal Pradesh. He completed his M.Phil in Instrumental Music from Rabindra Bharati University in 2016. Now pursuing a Ph.D. from the same university. Also a Post Graduate in Tabla from Rabindra Bharati University. Completed UGC Major Research Project from the Dept. of Vocal Music, Rabindra Bharati University. As a performing artist, he has visited Bhutan, Bangladesh. He has presented many papers in the National and International seminars \& conferences on Instrumental Music.

\section{SOURCES OF FUNDING}

This research received no specific grant from any funding agency in the public, commercial, or not-for-profit sectors.

\section{CONFLICT OF INTEREST}

The author have declared that no competing interests exist.

\section{ACKNOWLEDGMENT}

None.

\section{REFERENCES}

[1] Bandopadhayay, Sruti. (2010). Manipuri Dance, An Assessment on History and Presentation. Gurgaon: Subhi Publications.

[2] Danisana, R.K. (2012). Manipuri Dances. Rajesh Publication.

[3] Mitra, Kankana. (2015). The Pleasure of Rasa-Kirtana. Kolkata: Nakshatra.

[4] Saroj Nalini, A. (1980). The Religion of Manipur. Guwahati: Spectrum Publication.

[5] Sen, K. (2017). A Comparative Study and Assessment of the Manifestations of Chaitanite Vaishnavism on Odissi Dance \& Manipuri Dance. Ph.D. Thesis, Department of Dance, Rabindra Bharati University, Kolkata, West Bengal.

[6] Singh, D. M. (May, 2018). NATA SANKIRTANA AND MANIPURI SOCIETY. Granthaalayah, 476-480.

[7] Singh, Ksh. Kriti. (2017). Oja Gurusingdagi. Imphal: Ksh. Imocha Singh.

[8] Singha, B. (September, 2001). Cultural Relations Between Manipurl and Bengali: A Study on the Tendencies of Synthesis. Ph.D. Thesis, Manipuri Department, Assam University, Silchar, Assam.

[9] Singha, M. (April, 2009). Cultural Semiosis of Manipuri Nat Sankirtana. Ph.D. Thesis, Manipuri Department,Assam University, Silchar, Assam.

[10] Waikhom, Rangitabali. (2004). A HISTORICAL STUDY OF TRADITIONAL NIANIPURI THEATRE. Ph.D. Thesis, History Department, Manipur University, Imphal, Manipur. 